\author{
Magdalena Bobro \\ University of Rzeszów, Poland
}

\title{
Collective identity in the age of globalisation
}

\begin{abstract}
This article deals with the legal liability of collective person in the age of globalization. It touches the problem of the "person" in such fields as law, philosophy and sociology. The article presents the influence of globalisation on identity and the question of individualisation. Identity is defined as a process of internal and external adjustment. The processes of globalisation may contribute to the loss of cultural identity. The diverse nature of globalisation has given rise to new identities. Concurrently, the article also presents the challenges posed by globalisation, for instance: identity and freedom of individualisation versus community and belonging.

The author aims to make a short analysis according to the liability of collective persons throughout the history of civil and criminal law.
\end{abstract}

\section{Keywords}

Globalisation, identity, individual identity, collective identity, person, legal person, law system, civil law, criminal law, liability.

\section{The idea of globalization}

Civilisation changes, which are the result of many factors, form the basis for the process, involving both individuals and the community, known as globalisation.

The goal of globalization is the desire to unify the world for economic reasons by international capital groups, considering societies in categories of consumers 
of goods and services, rather than recipients of culture. ${ }^{1}$ Cultural models are subjected to a progressive standardization, especially in the field of popular and mass culture, which in some way is leading to a slow reduction of the importance of traditional, local ethnic cultures for the marketing McWorld. This kind of globalization means that ${ }^{2}$ "[...] breaking free from the influence of microenvironments is binding individuals with the increased influence of macrosystems. This applies to (...) the whole lifestyle under such forms of consumption. As a result, we receive world-wide human copies, which are more and more similar to each other in the forms of behaviour, preferences and attitudes. [...] The highly individualized consumer becomes a subject of the cultural unification regardless of the number of available choices, loses his individuality as a member of particular population, the nation, becoming a part of the new species, produced by the technological civilisation".

Globalization has its own supporters as well as opponents. Supporters, who mainly are promoters of neo-liberal ideology, argue that globalization is a positive, attractive, profitable and convenient phenomenon. It creates new opportunities for ordinary people and guarantees a higher level or better quality of life. ${ }^{4}$ It promotes economic, political and cultural solutions which are characteristic for Western societies, unifying the world according to a single design. ${ }^{5}$ Opponents, who mostly present conservative views, claim that globalization is an example of a moral crisis, ${ }^{6}$ because the cultural unification of the world is perceived as an evil destroying cultural diversity, understood as an important

1 T. Burdzik, Między indywidualizmem a zbiorowościa - globalizacja a tożsamość, ”Horyzonty Wychowania” 24 (2013), p. 67.

${ }^{2}$ B. J. Barber, Dżihad kontra McŚwiat, Warszawa 1997; G. Ritzer, Mcdonaldyzacja społeczeństwa, Wydawnictwo Muza, Warszawa 1997, in: V. Krawczyk-Wasilewska, Tożsamość podmiotu zbiorowego $w$ dobie globalizacji. Aspekt etniczno-kulturowy, „Civitas Hominibus: rocznik filozoficzno-społeczny" 1 (2006), p. 67.

${ }^{3}$ M. Hirszowicz, Spory o przyszłość. Klasa, polityka, jednostka, Wydawnictwo IFiS PAN, Warszawa 1998, p. 179, in: V. Krawczyk-Wasilewska, Tożsamość podmiotu zbiorowego $w$ dobie globalizacji. Aspekt etniczno-kulturowy, „Civitas Hominibus: rocznik filozoficzno-społeczny” 1 (2006), p. 67.

${ }^{4}$ T. L. Friedman, Lexus i drzewo oliwne. Zrozumieć globalizację, Rebis, Poznań 2001, p. 408, in: A. Nobis, Globalizacja jako postęp i kryzys, „Kultura i Wartości” 2 (2014).

${ }^{5}$ A. Nobis, Globalizacja jako postęp i kryzys, „Kultura i Wartości” 2 (2014), p. 41.

${ }^{6}$ I. Wallerstein, Koniec świata jaki znamy, Warszawa 2004, p. 68, in: A. Nobis, Globalizacja jako postęp i kryzys, „Kultura i Wartości” 2 (2014). 
value. ${ }^{7}$ Discussed through an economic dimension, globalization is criticised for exploitation, enslavement, destruction of such values as people's lives and their work and its effects. Therefore, economic development is also seen as recession. ${ }^{8}$

Globalization, which manifests a unification of civilisation, as well as joining communities into supranational organisations of a political or financial nature, is a new "battlefield", which rate is the choice of its own identity, so ambiguous in the world of liquid modernity. Mobility, which is possible for almost everyone, opens up new levels of identity construction, both as individual and collective subjects. ${ }^{9}$

Globalization evokes identity change because of the constant volatility of values that are promoted in the international cultural circulation. Diversity leads identity to be in a constant "marathon of changes" on the border of tradition and modernity, nature and technology, individuality and community. On the other hand, the community, which is the carrier of values, passes a specific model of the perception of the world during the socialization process, models of attitudes appropriate for individuals to achieve the best possible results of a compatible existence in the society. According to the theory of social identity, a part of one's own self-definition comes from membership in a social group and its relation to the values and emotional meaning given by the group Creating of an individual identity takes place through contact with other individuals and sharing common values. Social identity is a collection of feelings, attitudes and emotions in the community that lead to unity, and ultimately becomes part of the individual's identity. ${ }^{10}$

\section{Designation of a person and identity}

The concept of a person and identity is an essential issue for the article. These concepts are characterized by ambiguity and complexity. There are different concepts proposed by people hailing from the fields of art, legal sciences, theology

7 A. Nobis, Globalizacja jako postęp i kryzys, „Kultura i Wartości” 2 (2014), p. 42.

8 A. Nobis, Globalizacja jako postęp i kryzys, „Kultura i Wartości” 2 (2014), p. 38.

9 T. Burdzik, Między indywidualizmem a zbiorowościa - globalizacja a tożsamość, „Horyzonty Wychowania” 24 (2013), p. 60.

10 T. Burdzik, Między indywidualizmem a zbiorowościa - globalizacja a tożsamość, „Horyzonty Wychowania” 24 (2013), p. 63-65. 
and philosophy. Each of these visions came at a specific time and context. They play different roles and functions. Although the notion of a person did not appear in ancient philosophy, it played an important role in Roman law of the classical period: "In Roman law, 'persona' marked an individual understood as a certain status, ability, condition that was distinguishable from other statuses, abilities or condition". On the other hand "The people's right was known as the law related to various abilities or status, that people were in situations recognized by the legal system. The word 'persona' was not equated with the concept of human [...]. It can even be assumed that any author who writes in Latin did not use the term 'persona' as the concept forming an individual". ${ }^{11}$

Many attempts have been made over the centuries to define "a person". Descartes, John Locke, David Hume, Immanuel Kant, Daniel Dennett, Peter Strawson, Ludwig Wittgenstein, twentieth-century philosophers of dialogue are only some examples that have written about this concept in the history of philosophical research. ${ }^{12}$ In the 2oth century, in the Heideggerian philosophical perspective, one can find a comparison of the legal concept of 'person' to some mechanisms of human depersonalization, relying in leveling and homogenizing of people's attitudes and the accompanying phenomenon of losing the individual in the crowd. Heidegger describes these phenomena and mechanisms of collective life with the term "The One" / "the They" (das Man). It is the most common form of existence, when a person passively adapts to the environment, accepting blindly and repeating the activities, words and gestures of the collective. The person loses his individuality in the mass and succumbs to anonymous everyday routine. This conventional and figurative way of being is considered as "eternal", "natural" and the person does not dispute it. What is more, s/he feels calm and happy when s/he identifies him/herself with collective conformity, with that omnipotent "The One". According to Heidegger, the concept of "The One" is a life that is non-authentic, and thus a constant attempt to escape "a human from freedom and from the most important truth about himself" (that is a "fall", "loss of authenticity"). ${ }^{13}$ The "non-authentic" existence is the mode of existence in which a human loses his fundamental consciousness by escape from his

${ }_{11}$ W.E. Ball, St.Paul and the Roman Law and Other Studies on the Origin of the Form of Doctrine, T\&T Clark, Edynburg 1901, p. 79-80, in: R. Zyzik, Pojęcie osoby - jedno czy wiele?, "Racjonalia" 2 (2012), p. 9-10.

12 R. Zyzik, Pojęcie osoby - jedno czy wiele?, "Racjonalia” 2 (2012), p. 14.

13 T. M. Jaroszewski, Koncepcja życia autentycznego Martina Heideggera, „Etyka” 4 (1969), p. $131-132$. 
problems or by desire to forget about them. The "authentic" life, according to Heidegger, is the courage to take the whole truth about our existence on our shoulders. An authentic human is a human who "realized that he is nothingness, and evaluates his whole life based of this nothingness". He is also free because he is not under any pressure of "The One". He does not think through outside terms which are imposed upon him. He clearly understands that his actions "express only him and nothing moreover", that authentic announcing between people is impossible, but only "being-with" (Mitsein) based on understanding and respecting mutual non-communicativeness. Heidegger admits that a human needs other people, even to guarantee the physical possibilities of his life. He would also like to associate with them, however he has a tendency to treating them as "tools" to achieve his aspirations. Similarly, the community treats a human being as an instrument for its goals. For these reasons, and also due to the impossibility of trans-subjective communication between people, it is impossible to have any authentic community of people, but only their coexistence. ${ }^{14}$

Keeping in mind the concept of authentic or non-authentic existence of a person, according to Heidegger, which has only been briefly outlined above, it becomes obvious, that definitions of a person developed in philosophy by different authors cannot be used $a d h o c$, in isolation from their philosophical (or theological) context. None of the definitions is created in emptiness and each of them is based on a certain notional system: the classical one is supported by Aristotelianism, the psychological one is built on the Cartesian tradition, and the ethical one is derived from the transcendental philosophy of Kant. The 2oth century saw the emergence of new, analytical and naturalistic views of the subject, whilst largely not agreeing amongst themselves. s. It seems that - within philosophy and especially ethics - a "person" is an ambiguous concept, irreducible to one general definition. Therefore, the choice of a definition is partly arbitrary. Philosophy does not give us a simple solution to the riddle of "a person". ${ }^{15}$

There is a completely different notion of "a person" in the legal system than in philosophy. It is a purely normative category, evolving along the overall structure of legal cultures. Its introduction is not intended to describe a certain slice of reality. It plays the legal role of the "anchor point" for the rights and obligations attributed to people (and organizational units) by the legislator. Therefore,

14 T. M. Jaroszewski, Koncepcja życia autentycznego Martina Heideggera, „Etyka” 4 (1969), p. 133.

15 R. Zyzik, Pojęcie osoby - jedno czy wiele?, „Racjonalia” 2 (2012), p. 22. 
too easy transitions between a particular definition of a person in philosophy and the concept of a person in law threatens with the error of equalization. ${ }^{16}$

In the case of the term "identity", we encounter similar definitional problems, which is still an authentic subject of scientific discussion. This discussion concerns both the self-identification of the individual, as well as types of identities resulting from the relationship between individuals experiencing one's own existence one's interaction with a certain community. There are two main characteristics among the many that shape each human being: personal and social. ${ }^{17}$

The personal identity can be divided into individual identity, as each human's identity, and group identity, as a certain sum of individual identities:

a) individual identity - it is the ability of a person to determine who he is, it refers to the awareness of one's cohesion in time and space and the reflection on the place it occupies in the surrounding reality. It is also the ability to distinguish oneself from others;

b) group identity - it is defined as the sum of individual identities which are a part of a certain group. Individuals, who are shaping group identity, refer to the following concepts: a sense of connection with a certain group, which is supported by shared knowledge about their origin, historical continuity of the group and awareness of certain separateness from others. The group will maintain its identity as long as its members refer to it in the process of self-determination. ${ }^{18}$

The social form of the identity is expressed by the national, regional, ethnic and cultural aspect on the spatial level:

a) national identity - refers to collective historical consciousness, supported by the existence of traditional administrative institutions (organization of the statehood) and institutions that collect and popularize national achievements (f. e. schools, museums, libraries, theatres, etc.). This kind of identity is united with the assimilation of certain symbolic culture expressed among others with language, religion, customs etc.; ${ }^{19}$

${ }^{16}$ R. Zyzik, Pojęcie osoby - jedno czy wiele?, „Racjonalia” 2 (2012), p. 29-30.

17 V. Krawczyk-Wasilewska, Tożsamość podmiotu zbiorowego $w$ dobie globalizacji. Aspekt etniczno-kulturowy, „Civitas Hominibus: rocznik filozoficzno-społeczny” (2006), p. 63.

${ }^{18}$ K. Waszczyńska, Wokół problematyki tożsamości, „Rocznik Towarzystwa Naukowego Płockiego" 6 (2014), p. 53-55.

19 A. Kłoskowska, Kultury narodowe u korzeni, Warszawa, PWN 1996; L. Zdybel (ed.), Być $w$ narodzie. Szkice o idei narodu, narodowej kulturze i nacjonalizmie, Lublin, Wydawnictwo UMCS 1998; W. Pisarek, Obce kultury narodowe w świadomości Polaków, Kraków, Ośrodek Badań Porównawczych 1990; Z. Bokszański, Stereotypy a potoczne wyobrażenia narodów 
b) regional identity - it is a variation of national identity idea, which is associated with the place of residence of certain ecumena and the concept of the so-called "regional homeland" or "small homeland". It fulfills a substitutive function in relation to the too-distant and too-general concept of national identity; ${ }^{20}$

c) ethnic identity - it is connected with the phenomenon of the existence of certain ethnos in a geographically defined area. Etnos is a human group that is aware of its specific community and differentiates itself from other similar formations, and feels the need of lasting in tradition; ${ }^{21}$

d) cultural identity - it is historically determined by both external factors (confrontation with other cultures) and internal factors (traditional models, norms, values, moral and ritual heritage, etc.). Cultural identity is the continuity of tradition, language, norms and values, and models of behaviour, which are cultivated from generation to generation. It is also a community consciousness owed by members of certain human groups, who share historical and territorial fates. $^{22}$

i grup etnicznych, „Kultura i Społeczeństwo” 2 (1994), p. 53-65, in: V. Krawczyk-Wasilewska, Tożsamość podmiotu zbiorowego $w$ dobie globalizacji. Aspekt etniczno-kulturowy, „Civitas Hominibus: rocznik filozoficzno-społeczny" 1 (2006), p. 64.

20 J. Damrosz, Symbolika regionu jako wyznacznik odrębności, Opole, Instytut Śląski 1988; M. Wieruszewska, Tożsamość kulturowa jako wartość i czynnik konstruktywny społeczności lokalnej, Warszawa, Wydawnictwo Uniwersytetu Warszawskiego 1989; S. Bednarek, W kręgu małych ojczyzn. Szkice regionalistyczne, Wrocław-Ciechanów, KODRTK 1996, in: V. KrawczykWasilewska, Tożsamość podmiotu zbiorowego w dobie globalizacji. Aspekt etniczno-kulturowy, „Civitas Hominibus: rocznik filozoficzno-społeczny” 1 (2006), p. 64.

${ }^{21}$ A. N. Kovačev, Tożsamość etniczna - powstawanie, obrona i prześladowanie, in: J. Nizińska (ed.), Tożsamość podmiotu zbiorowego, „Colloquia Communia” 3 (2000), p. 125-144; J. V. Bromlej, Oczerki tieorii etnosa, Moskva 1973; V. Krawczyk-Wasilewska, Folklor i folkloryzm jako wyraz tożsamości, in: V. Krawczyk-Wasilewska, Wspótczesna wiedza o folklorze, Warszawa, LSW 1986, p. 55-58; K. Kwaśniewski, Etnos, in: Z. Staszczak (ed.), Słownik etnologiczny. Terminy ogólne, Warszawa-Poznań, PWN 1987, p. 110-111; W. Lippmann, Public Opinion, New York-Baltimore, Tuchstone Books 1922; A. Schaff, Stereotyp. Definicja i teoria, „Kultura i Społeczeństwo" 3 (1978); A. P. Wejland, Obrazy grup społecznych. Studium metodologiczne, Warszawa, IFiS PAN 1991; Z. Bokszański, „Stereotypy a kultura, Wrocław, Ossolineum 1997; V. Krawczyk-Wasilewska, Współczesna wiedza o folklorze, Warszawa, Ludowa Spółdzielnia Wydawnicza 1986, p. 56, in: V. Krawczyk-Wasilewska, Tożsamość podmiotu zbiorowego w dobie globalizacji. Aspekt etniczno-kulturowy, „Civitas Hominibus: rocznik filozoficzno-społeczny” 1 (2006), p. 64.

${ }^{22}$ V. Krawczyk-Wasilewska, Tożsamość podmiotu zbiorowego $w$ dobie globalizacji. Aspekt etniczno-kulturowy, „Civitas Hominibus: rocznik filozoficzno-społeczny” 1 (2006), p. 65. 
For a philosopher, identity is associated with moral responsibility. It is a task that stands before each of us. Language, which is a social phenomenon, causes that our individual narrative is only a part narration of the community, the narration of our cultural circle. ${ }^{23}$

The recalled category of narration is a part of the understanding issue, which does not seem to be indifferent for a human life and human experience, because it defines our way of seeing the world, ourselves and other human being. Narration is considered as a kind of cognitive category, because the narration organizes our experience, our way of seeing reality and understanding ourselves. Moreover, there is a shift to the ontological and anthropological dimension, closely linking the narrative category with the notion of identity. ${ }^{24}$

Collective identity is considered as a moral responsibility, which has been formalized in a certain aspect, included in the rules of law. This shall be discussed in the following sections.

\section{Collective identity in law and its liability}

Mankind has achieved great technological progress, but there is a problem with defining the limits of one's actions to achieve the intended goal. Should there be any legal and moral borders in this area? Should the collective identity be guided by moral values or should it be a subject of the rules of law? The readiness of collective entities to participate in a united, global world does not always go hand in hand with their openness to comply with certain principles and legal regulations. This, prompts many countries to reflect on the issue of collective identities' liability.

Collective identities' liability is interesting because of its timeliness, although it is not a new issue. Traditional criminal law has become inadequate

${ }^{23}$ B. Baszczak, Tożsamośćczłowieka a pojęcie narracji, „Analizai Egzystencja” 14 (2011), p. 138. The confirmation of these implications are the words of Ch. Taylor: "I am a subject only in relation to certain interlocutors: in a relation to those who played a key role in the process of my self-determination; in another relation - to those who currently have decisive meanings for my continued command of the languages of self-understanding". Ch. Taylor, Źródła podmiotowości wspótczesnej. Narodziny tożsamości nowoczesnej, Warszawa, PWN 2001, p. 70.

${ }^{24}$ B. Baszczak, Tożsamość człowieka a pojęcie narracji, „Analiza i Egzystencja” 14 (2011), p. 140. 
and powerless in the aspect of the proper implementation of the various functions of the penalty and the full and comprehensive identification of the crime's perpetrator.

The so-called spirit of the community or a sense of super-personal and shared interests is the criminological circumstance, which supports the crime of collective identities (also known as legal persons in the legal system). It causes the lack of condemnation of specific behaviour by such a community, and thus it displays the lack of expiation by the perpetrator (voluntary disclosure).

The status of a legal person is an artificial creation. However it has an unquestionable influence on the shape and functioning of today's world. Granting a certain community a person's status is one of the most enduring institutions of law and, at the same time, one of the most commonly recognized legal fictions. ${ }^{25}$

A legal person may be a subject to liability either under civil or criminal law.

Roman ius civile initially recognized only a private party as a legal person. However the State, and then the municipalities and associations of private parties, were identified with corporations. Roman corporation was understood as the majority of its members with a changeable composition, but none of these members could independently dispose of corporate's assets. ${ }^{26}$ Establishing the concept of legal person occurred in Justinian's law (the $6^{\text {th }}$ century A.D.).

Today's European legal systems distinguish two fundamental concepts of the functions of a legal person: a method of general formulation of legal person, allowing the legislator to recognize, as legal person, any organizational unit possessing the features listed in the Act, and a normative method adopted by Polish codifiers, consisting in granting specific legal personality to specific entities by law. ${ }^{27}$

Possessing legal capacity by a legal person causes the possibility of bearing legal liability by this kind of person. ${ }^{28}$

The sources of criminal liability of collective entities should be sought in Roman law, which assumed that the accusation could be directed only against the

${ }^{25} \mathrm{http}$ //personalizm.pl/polrocznik/numer-4/korporacja-nie-jest-osoba/ (20.06.2016).

${ }^{26}$ Ulpian: „Si quid universitati debetur, singulis non debetur; nec quod debet universitatis, singuli debent" (D. 3, 4, 7, 1), in: W. Litewski, Rzymskie prawo prywatne, Wydawnictwa Prawnicze PWN 1999, p. 135, 136.

27 Z. Radwański, Prawo cywilne - część ogólna, C. H. Beck 1997, p. 159.

28 B. Namysłowska - Gabrysiak, Odpowiedzialność karna osób prawnych, C. H. Beck 2003, p. 10. 
one who was ruling the city. The accusation could not be directed against the city. ${ }^{29}$

Criminal liability for someone else's acts appeared in medieval Poland and Europe, and it was divided into collective liability ${ }^{30}$ (an example of the existence of the phenomenon of such responsibility in our modern times is the structure of mafia "families"31) and individual liability.

With the consolidation of State authority collective responsibility of territorial unions has been limited. Individualization of responsibility was a goal to achieve, ${ }^{32}$ which based its assumptions on "two main authorities of the era: Holy Bible and Roman law". ${ }^{33}$ Till today the doctrine of the Catholic Church is faithful to the principles interpreted at that time. ${ }^{34}$

The end of the $18^{\text {th }}$ century initiated the development of the doctrine of individualization of criminal responsibility, and the $19^{\text {th }}$ century tried to remove the remnants of all collective liability.

Criminal liability of legal person is an institution currently adopted by the majority of European countries.

\section{The conclusion}

Globalization brings many changes in the life of the individual human being, as well as entire nations. Multilevel changes affect the social, political, economic and cultural spheres. It is even said to shape global consciousness and that is why the question of identity arises.

On one hand, the culture of individualism promotes such values as originality, self-realisation or authenticity, but on the other hand it does not offer

${ }^{29}$ Ulpian, „De dolo decurionum in ipsos decuriones de dolo actio”.

${ }^{30}$ S. Płaza, Historia prawa w Polsce na tle porównawczym, część I: X - XVIII w.; część II: Polska pod zaborami, Księgarnia Akademicka, Kraków 1998, p. 395, 376-377. Such liability was provided by the Statutes of Casimir the Great (1310 - 1370), 1356 - 1362? A. D. $117,129$.

${ }^{31}$ M. Puzo, Ojciec chrzestny, Warszawskie Wydawnictwo Literackie Muza s. a. 2002, p. 106,

32 Burgundy Lex Gundobada (II poł. V w.) constituted: "relatives of the killed person (...) have to pursue only the perpetrator. We command to destroy the perpetrator, but we won't let the innocents suffer".

${ }^{33}$ K. Sójka - Zielińska, Historia prawa, PWN 1989, p. 168.

${ }^{34}$ Z. Grocholewski, Filozofia prawa w nauczaniu Jana Pawła II, Poznań 1996, p. 27. 
clear choices or solutions. Globalization proclaims the standardization of the world, which strengths are going to be the similarities between people, the increase in the impact of communication and the reduction of differences. It is easy to see that the globalization process rapidly triggers individualism in collective societies. The apparent "liberation" of the individual's identity through actions aimed at affirmation of "ego" and indicating personal uniqueness, in fact is not an action which separates individuals from their community, but it is a confirmation of the homogenization of society. Individualism is promoted as a synonym of creativity. However the manifestation of one's own uniqueness in society is sometimes limited to some variants promoted by the mass media. Fashion, music and film offer a specific range of possibilities and therefore it is difficult to talk about influencing the shape of one's own choices, if - in the majority - they have a source in the mainstream media. The individualization of individuals is nothing else but the institutionalization of individual choices. ${ }^{35}$

Considering the problem of "person" at the interface between such disciplines as law, philosophy and sociology makes us think about the form of individualism philosophically formed into the Heideggerian forms of "The One" / "The They" and sanctioned within the law. Where will the postmodern model of individualization, in which individuals are not aware of the appearance of their own choices, lead us? Apparent pride of apparent freedom is built in society. This may fill some with fear, because this kind of attitude favors the uncritical reception of reality and the image created by the media. Globalization demonstrates the formation of a new world order designed by global forces. ${ }^{36}$ An unspecified relativism and universalism of values, which constitutes the ideological direction of globalism, notrooted in the tradition of recipients who are diversified, is promoted through globalization. The main carrier of globalization and modern values, constituting an important, competitive field for local, national and religious identities is contemporary culture in various forms. ${ }^{37}$

A common is for legislators' to be capable of wise reflection, which will be able to find a golden mean between the meaning of the "person" and its liability, and the application of the principle of justice on the basis of legal rules.

35 T. Burdzik, Między indywidualizmem a zbiorowościa - globalizacja a tożsamość, „Horyzonty Wychowania” 24 (2013), p. 67-69.

36 T. Burdzik, Między indywidualizmem a zbiorowościa - globalizacja a tożsamość, „Horyzonty Wychowania” 24 (2013), p. 70.

37 T. Burdzik, Między indywidualizmem a zbiorowościa - globalizacja a tożsamość, „Horyzonty Wychowania” 24 (2013), p. 65-66. 
On the other hand, the sphere of social relations, which is a natural mirror of normative regulations, should open itself to humanization and personalization of life, to the realisation that values such as family, love and friendship do not stand in the way of achieving wealth or prestige. It is on the contrary of this thought. They strengthen the sense of unity in diversity, emphasizing the uniqueness of each identity.

\section{Bibliography}

Baszczak B., Tożsamość człowieka a pojęcie narracji, „Analiza i Egzystencja” 14 (2011), pp. 123-140.

Burdzik T., Między indywidualizmem a zbiorowościq - globalizacja a tożsamość, „Horyzonty Wychowania” 24 (2013), pp. 59-73.

Edwards J., Inkwizycja hiszpańska, Grupa Wydawnicza Bertelsmann Media, Fakty 2002.

Grocholewski Z., Filozofia prawa w nauczaniu Jana Pawła II, Księgarnia Św. Wojciecha, Poznań 1996.

Jaroszewski T. M., Koncepcja życia autentycznego Martina Heideggera, „Etyka” 4 (1969), pp. 119-138.

Krawczyk-Wasilewska V., Tożsamość podmiotu zbiorowego $w$ dobie globalizacji. Aspekt etniczno-kulturowy, „Civitas Hominibus: rocznik filozoficzno-społeczny” 1 (2006), pp. 63-71.

Litewski W., Rzymskie prawo prywatne, PWN 1999.

Namysłowska - Gabrysiak B., Odpowiedzialność karna osób prawnych, C. H. Beck 2003.

Nobis A., Globalizacja jako postęp i kryzys, „Kultura i Wartości” 2 (2014), pp. 35-44.

Osuchowski W., Zarys rzymskiego prawa prywatnego, Warszawa 1971.

Paleczny T., Typy tożsamości kulturowej a procesy globalizacji, UJ, Kraków, www.uj.edu. $\mathrm{pl} /$ documents/ 3337228/f4bd2586-f422-47fd-8c12-1eae08b73aa0 (11.12.2017).

Płaza S., Historia prawa w Polsce na tle porównawczym, część I: X - XVIII w.; część II: Polska pod zaborami, Księgarnia Akademicka, Kraków 1998.

Pniewska M., Problematyka charakteru prawnego odpowiedzialności podmiotów zbiorowych za czyny zabronione pod groźbą kary w prawie polskim, „Studia Iuridica Toruniensia" tom VI (2010), pp. 182-206.

Puzo M., Ojciec chrzestny, Warszawskie Wydawnictwo Literackie Muza s. a. 2002.

Radwański Z., Prawo cywilne - część ogólna, C. H. Beck 1997.

Skwarczyński H., Odpowiedzialność podmiotów zbiorowych jako nowy rodzaj odpowiedzialności za czyny zabronione pod groźbą kary, „Palestra” 1-2 (2004), pp. 84-98.

Sójka - Zielińska K., Historia prawa, PWN 1989. 
Taylor Ch., Źródła podmiotowości współczesnej. Narodziny tożsamości nowoczesnej, Warszawa, PWN 2001.

Waszczyńska K., Wokót problematyki tożsamości, „Rocznik Towarzystwa Naukowego Płockiego" 6 (2014), pp. 48-73.

Zyzik R., Pojęcie osoby - jedno czy wiele?, „Racjonalia” 2 (2012), pp. 5-31.

http://www.edukacjaprawnicza.pl/aktualnosci/a/pokaz/c/aktualnosc/art/odpowiedzialnosc-podmiotow-zbiorowych-za-czyny-zabronione-pod-grozba-kary-wybranezagadnienia.html (20.06.2016).

http://personalizm.pl/polrocznik/numer-4/korporacja-nie-jest-osoba/ (20.06.2016).

https://repozytorium.ka.edu.pl/ (13.06.2017). 